\title{
Laboratorial significance of autoantibodies of dense fine speckled pattern
}

\author{
Tania Caroline Castro ${ }^{*}$, Daniela Petry Piotto \\ From 2011 Pediatric Rheumatology Symposium sponsored by the American College of Rheumatology \\ Miami, FL, USA. 2-5 June 2011
}

\section{Purpose}

Indirect immunofluorescence (IIF) in Hep-2 cells is the standard screening test for antinuclear antibodies (ANA). Advances in this methodology have brought up a considerable increase in sensitivity and consequently a decrease in its specificity. This has resulted in an increasing number of positive tests in apparently healthy subjects. In particular, autoantibodies associated with the dense fine speckled (DSF) ANA-Hep-2 pattern, has been largely detected in apparently healthy individuals.

\section{Methods}

ANA-Hep-2 test from 921 children aged 0.2 to 13.9 years was retrospectively retrieved from the routine of a large private laboratory on-site certified by the College of American Pathologists (CAP). Criteria for patient selection included concomitant existence of at least, one or more of the following tests (complete blood count, erythrocyte hemossedimentation rate [ESR], C - reactive protein [CRP], ferritin, protein electrophoresis and urinalysis). The frequency of ANA-Hep-2 patterns was analyzed according to alterations in those exams. Statistical analysis included Fisher's exact test, Analysis of Variance (ANOVA), Kruskal-Wallis test, Mann-Whitney test with Bonferroni correction and Kolmogorov-Smirnov test.

\section{Results}

ANA-Hep-2 was positive in 38\% (350/921) of the total children, and the frequency of DFS pattern was observed in $13.4 \%(123 / 921)$ of the total children and in $35.1 \%$ (123/ 350) of those with ANA-Hep-2 positive test (Table 1). DFS pattern was significantly correlated with higher levels of CRP $(\mathrm{p}<0.01)$ and lymphocytes $(\mathrm{p}<0.02)$, although, in normal levels.
Table 1 Immunofluoresence patterns of antinuclear antibodies

\begin{tabular}{lll}
\hline ANA & $\mathrm{N}$ & $\%$ \\
\hline Total & 921 & 100.0 \\
Non Reagent & 571 & 62.0 \\
Homogenous/Specified & 9 & 1.0 \\
Dense Fine Specified & 123 & 13.4 \\
Quasi-homogenous & 37 & 4.0 \\
Centromere & 8 & 0.9 \\
Others & 173 & 18.8 \\
\hline
\end{tabular}

\section{Conclusion}

The DFS pattern was a frequent finding in the ANAHep-2 routine and its occurrence was not associated with abnormalities in general laboratory tests. This finding supports the notion that the autoantibodies associated with the DSF ANA-Hep-2 pattern are common in individuals with no apparent health abnormality.

\section{Disclosure}

Tania Caroline Castro: None; Daniela Petry Piotto: None.

Published: 13 July 2012

doi:10.1186/1546-0096-10-S1-A121

Cite this article as: Castro and Piotto: Laboratorial significance of autoantibodies of dense fine speckled pattern. Pediatric Rheumatology 2012 10(Suppl 1):A121.

Federal University of São Paulo, Sao Paulo, Brazil

(c) 2012 Castro and Piotto; licensee BioMed Central Ltd. This is an Open Access article distributed under the terms of the Creative Commons Attribution License (http://creativecommons.org/licenses/by/2.0), which permits unrestricted use, distribution, and reproduction in any medium, provided the original work is properly cited. 